\title{
New Methodologies for Qualitative and Semi-Quantitative Determination of Carbon-Centered Free Radicals in Cigarette Smoke Using Liquid Chromatography-Tandem Mass Spectrometry and Gas Chromatography-Mass Selective Detection*
}

\author{
by \\ Anthony R. Gerardi and William M. Coleman III \\ R.J. Reynolds Tobacco Co., 950 Reynolds Boulevard, Winston-Salem, NC 27105, USA
}

\section{SUMMARY}

Several approaches were explored to develop a high throughput procedure for relative determination of 14 different carbon-centered free radicals, both acyl and alkylaminocarbonyl type, in cigarette smoke. Two trapping procedures using 3-cyano-2,2,5,5-tetramethyl-1pyrrolidinyloxy, or 3-cyanoproxyl radical (3-CNP) were designed for this study: a) trapping in solution and b) trapping on a solid support which was a Cambridge filter pad. Fresh whole smoke and vapor phase smoke from mainstream cigarette smoke from Kentucky Reference Cigarettes 2R4F, as partitioned via an unadulterated Cambridge filter pad, were transferred into each trapping system in separate experiments. The 3-CNP coated Cambridge filter pad approach was shown to be superior to the impinger procedure as described in this study. Gas chromatography coupled with mass selective detection (GC-MS) was employed for the first time as an alternate means of detecting several relatively highly concentrated radical adducts. Liquid chromatography tandem mass spectrometry (LC-MS/MS) with precursor ion monitoring and selected ion monitoring (SIM) was used for detecting the large array of radicals, including several not previously reported: formyl, crotonyl, acrolein, aminocarbonyl, and anilinocarbonyl radicals. Relative quantitation was achieved using as external calibration standards of 4-(1pyrrolidino)benzaldehyde and nicotine. It was determined that the yield of carbon-centered free radicals by reference cigarette $2 \mathrm{R} 4 \mathrm{~F}$ was approximately 265 nmoles/cigarette at $35 \mathrm{~mL}$ puff $/ 60 \mathrm{sec}$ interval $/ 2 \mathrm{sec}$ duration smoking conditions. [Beitr. Tabakforsch. Int 24 (2010) 58-71]

\section{KEYWORDS}

Free Radicals, carbon-centered radicals, liquid chromatography, HPLC, mass spectrometry, LC-MS/MS, gas chromatography, GC-MS

\section{ZUSAMMENFASSUNG}

Es wurden verschiedene Ansätze untersucht, um ein Verfahren zu entwickeln, das in einem hohen Durchsatz 14 verschiedene freie Radikale mit zentralem C-Atom vom Acyl- und Alkylaminocarbonyl-Typ in Zigarettenrauch bestimmt. Für diese Untersuchung wurden zwei Auffangverfahren, bei denen 3-cyano-2,2,5,5-tetramethyl-1pyrrolidinyloxy- oder 3-cyanoproxyl-Radikal (3-CNP) für die relative Bestimmung verwendet wurden, ausgearbeitet: a) das Auffangen in Lösung und b) das Auffangen auf einem festen Träger, hier ein Cambridge-filter. Frischer Gesamtrauch und die Gasphase des Hauptstromrauchs der Kentucky Referenzzigarette 2R4F, welcher einen unveränderten Cambridgefilter passiert hat, wurden in separaten 
Experimenten in das jeweilige Auffangsystem geleitet. Bei den hier beschriebenen Verfahren, war der Ansatz mit 3CNP beschichtetem Cambridgefilter gegenüber der Auffangmethode in der Gaswaschflasche überlegen. Zum ersten Mal wurde alternativ Gaschromatographie gekoppelt mit massenselektiver Detektion (GCMS) zur Bestimmung von Radikaladdukten in relativ hoher Konzentration verwendet. Um einen großen Bereich von Radikalen zu detektieren, inklusive verschiedener Ionen, über die vorher noch nicht berichtet wurde: Formyl-, Krotonyl-, Acrolein-, Aminocarbonyl- und Anilinocarbonyl-Radikale, wurde Flüssigchromatographie mit gekoppelter Tandem-Massenspektrometrie (LC-MS/MS), sowie vorgeschaltetem Ionenmonitoring und selektivem Ionenmonitoring (SIM) verwendet. Eine relative Quantifizierung wurde durch die externen Kalibrierungsstandards 4-(1-pyrrolidino)benzaldehyd und Nikotin erreicht. Der Gehalt von freien Radikalen mit zentralem C-Atom im Rauch der Kentucky Referenzzigarette 2R4F, ermittelt bei den Abrauchkonditionen $35 \mathrm{~mL}$ Zugvolumen, $1 \mathrm{Zug} / 60 \mathrm{sec}$, Intervall/2 sec, lag bei etwa $265 \mathrm{nmol} /$ Zigarette. [Beitr. Tabakforsch. Int 24 (2010) 58-71]

\section{RESUME}

Plusieurs approches ont été explorées pour développer une procédure à haute performance pour la détermination relative de 14 radicaux libres centrés sur le carbone, de type à la fois acyle et alkyle aminocarbonyle, dans la fumée de cigarette. Deux procédés de piégeage utilisant le 3-cyano2,2,5,5-tétraméthyl-1-pyrrolidinyloxy, ou le radical 3cyanoproxyl (3-CNP) ont été conçus pour cette étude: a) le piégeage dans une solution et $b$ ) le piégeage sur un support solide à savoir un tampon-filtre Cambridge. La totalité de la fumée fraîche et la fumée en phase vapeur de la fumée principale des cigarettes de référence Kentucky 2R4F, telles que séparées par un tampon-filtre Cambridge non modifié ont été transférées à un système de piégeage lors d'expériences distinctes. L'approche avec le filtre Cambridge enduit de 3-CNP s'est avérée supérieure à la procédure avec impacteur telle que décrite dans cette étude. La chromatographie en phase gazeuse avec détection sélective de masse (GC-MS) a été employée pour la première fois comme méthode alternative de détection de plusieurs adduits radicaux de concentration relativement élevée. La chromatologie phase liquide couplée à la spectrométrie de masse en tandem (LC-MS/MS) avec un contrôle des ions précurseurs et un contrôle des ions sélectionnés (SIM) a été utilisée pour détecter une large gamme de radicaux, dont plusieurs qui n'avaient pas été reportés au préalable: formyl, crotonyl, acroléine, aminocarbonyl, et des radicaux anilinocarbonyl. Une quantification relative a été réalisée en utilisant des normes de calibration externes de 4-(1pyrrolidino)benzaldehyde et de nicotine. Il a été déterminé que le taux de radicaux libres centrés sur le carbone dans la cigarette de référence $2 \mathrm{R} 4 \mathrm{~F}$ était approximativement de 265 nmoles/cigarette dans des conditions de durée de fumage de $35 \mathrm{~cm}^{3}$ par bouffée $/ 60 \mathrm{sec}$. à intervalle de $2 \mathrm{sec}$. [Beitr. Tabakforsch. Int 24 (2010) 58-71]

\section{INTRODUCTION}

Free radical reactions are important to understanding toxicity, harm, and oxidative stress associated with cigarette smoking (1-7). Radicals are presumed to be highly reactive and short-lived though stable free radicals have been demonstrated in aged whole smoke (WS) and mainstream vapor phase (MSVP) minutes after combustion $(8,9)$. Radicals in the gas phase have been reported as both alkoxyl (RO) and carbon-centered (R') radicals. These radicals were demonstrated to have apparent lifetimes of greater than 5 minutes (10-12). Particulate phase radicals have shown much greater lifetimes with stability measured in hours for hydroquinone/semiquinone/quinone radicals trapped in polymers. Typical analysis of free radicals in smoke utilizes electron paramagnetic resonance (EPR) and requires separation of gas and particulate phase smoke components (13-16). While this methodology is useful, it does not provide structure or identification of free radicals present in smoke.

Recent studies have provided methodologies in which nitroxide radical scavengers, 3-amino-proxyl radical (3AP) and 3-cyano-proxyl radical (3-CNP), are used to selectively form stable diamagnetic adducts with carbon-centered radicals through a gas-solid phase reaction (17-20). This is achieved by passing fresh whole smoke or vapor phase smoke through a distillation column containing glass beads coated with one of the radical scavengers aforementioned. The glass beads were washed and either analyzed by LC-MS/MS with precursor ion monitoring $(19,20)$ or derivatized with a fluorescent reagent and analyzed by HPLC with fluorescence detection $(17,18)$. Other groups have developed LC-MS/MS methods for determining alkoxyl (RO) and hydroxy ( $\mathrm{OH})$ radicals by spin-trapping the radicals with commercially available spin traps such as TEMPO $(6,21,22,23)$.

This work continued to utilize LC-MS/MS precursor ion monitoring but also incorporated moderately cheaper and relatively more accessible GC-MS. We have continued to make improvements to previous procedures (17-20) by coating a Cambridge filter pad with the radical scavenger reagent, 3-CNP, instead of glass beads. This greatly increased sample throughput, thus adding a means to statistically examine larger data sets. GC-MS, though not as sensitive as LC-MS/MS, proved useful in detecting several of the more relatively highly concentrated carbon-centered free radical adducts and, therefore, is proposed as a screening tool.

For relative quantitation, 4-(1-pyrrolidino)benzaldehyde (PBA) and nicotine, with $\mathrm{m} / \mathrm{z} 175.2$ and 163.2 respectively, were chosen for external calibration. The structure and masses of these two molecules are used as models for adducts formed between 3-CNP and carbon-centered free radicals in smoke. Also, since nicotine is present in smoke at known concentrations, it serves as an analytical anchor. Purified standards of the radical adducts found in this work have not been commercially identified. 


\section{EXPERIMENTAL SECTION}

\section{Materials}

Acetone, methanol (MeOH) and acetonitrile (ACN), HPLC grade, were obtained from Burdick and Jackson (Morristown, NJ) and 3-cyanoproxyl (3-CNP), 4-(1pyrrolidino)benzaldehyde (PBA), nicotine and formic acid (99.9\%) from Aldrich Chemical Company (St. Louis, MO). Solutions of $3-\mathrm{CNP}$ at $500 \mu \mathrm{g} / \mathrm{mL}$ and $50 \mathrm{mg} / \mathrm{mL}$ were prepared fresh just before use. LC-MS grade water used for pad extraction and LC mobile phase was acquired from Fisher (Pittsburg, PA). Standard solutions of 4-(1pyrrolidino)benzaldehyde and nicotine were prepared in 95:5 v/v ACN:water in a range from $3-80 \mu \mathrm{g} / \mathrm{mL}$.

\section{Smoke collection and derivatization - Impinger}

Mainstream smoke samples from five 2R4F reference cigarettes (University of Kentucky, Lexington, KY, USA) were collected on a Heinrich Borgwaldt RM20 rotary smoke engine (Heinrich Borgwaldt GmbH, Hamburg, Germany). The smoking regimen used to collect samples was $35 / 60 / 2$; a $35 \mathrm{~mL}$ puff taken every 60 seconds with a 2 second puff duration. Cigarettes were conditioned prior to smoking, for a minimum of 24 hours, in a laboratory with an environment of $75 \pm 2{ }^{\circ} \mathrm{F}$ and relative humidity at $60 \pm 2 \%$. The particulate matter or mainstream particulate phase smoke (MSPP) phase was collected electrostatically. After collection, the electrostatic tube was washed thoroughly with $20 \mathrm{~mL}$ of acetone containing 3-CNP.

For MSVP collection, four $25 \mathrm{~mL}$ impingers, containing five $\mathrm{mL}$ of acetone or acetonitrile with dissolved 3-CNP, were connected in series, and were placed aft of the electrostatic collector. For collection in acetone, the first impinger was cooled in ice water and the remaining three were chilled to $-70^{\circ} \mathrm{C}$, in an isopropanol/dry ice bath, prior to smoking. For collection in acetonitrile all four impingers were chilled in ice water. Prior to smoking, the puff volume was verified and the machine checked for leaks. The validity of the smoke runs was determined by comparison of the wet total particulate matter (WTPM) and puffs/cigarette from the run with those from 35/60/2 smoking analysis.

Whole smoke (WS) was passed directly into the four 25 $\mathrm{mL}$ traps containing $5 \mathrm{~mL}$ each of the $3-\mathrm{CNP}$ solution at $100 \mu \mathrm{g} / \mathrm{mL}$. Subsequent experiments employed an increased 3-CNP concentration, $500 \mu \mathrm{g} / \mathrm{mL}$. After WS collection the four traps were combined, samples were taken, and immediately placed in a dark GC vial for analysis. In a second set of experiments, the traps were analyzed separately. In a third set of experiments a concentrated solution of the spin trapping reagent, 3-CNP, was added to the trap samples at selected times after collection of the smoke samples.

\section{Smoke collection and derivatization - Cambridge filter pad}

The same smoking machine configuration and number of 2R4F cigarettes were used for collection of mainstream WS and MSVP onto the 3-CNP coated Cambridge filter pad. $50 \mathrm{mg}$ of $3-\mathrm{CNP}$ was dissolved in $1 \mathrm{~mL}$ of acetone which was then pipetted onto the rough side of a Cambridge filter pad using a circular motion moving from the center of the pad out. The filter pad was placed under a nitrogen stream for 2 minutes or until dry, similar to methodology used for carbonyl analysis using DNPH coated filter pads. For WS collection, the coated filter pad was placed in a holder directly aft of the smoking port on the smoking machine.

For MSVP collection, a clean Cambridge filter pad was placed in the holder directly aft the smoking port, followed by 2 inches of inert tubing and another pad holder containing the 3-CNP coated pad. The validity of the smoke runs was determined by comparison of the wet total particulate matter (WTPM) and puffs/cigarette from the run with those from 35/60/2 analysis. Immediately after smoke collection of the five $2 \mathrm{R} 4 \mathrm{~F}$ cigarettes, the coated pad was extracted with $50 \mathrm{~mL}$ of 95:5 (v:v) acetonitrile: water in an Erlenmeyer flask for 30 minutes at $300 \mathrm{rpm}$ on an orbital shaker. The extract was filtered with a $0.45 \mu \mathrm{m}$ PTFE Whatman Syringe into an amber LC vial and analyzed immediately or stored at $4{ }^{\circ} \mathrm{C}$ for later analysis. The 3-CNP radical adducts (3-CNP-R) were stable for at least 1 week.

\section{$G C / M S$}

Analysis conditions on a DB-5MS column appear in Table 1. Separations employing columns having a relatively polar phase, DBWAXetr and a relatively non-polar phase, DB1701, were also investigated and found to offer no improvement in component resolution or sensitivity.

\section{$L C-M S / M S$}

The HPLC used for separation of the 3-CNP-R was a Thermo Surveyor MS Liquid Chromatograph (San Jose, CA) using a Phenomenex (Torrance, CA) Gemini-NX 5 $\mu \mathrm{m}, 2.1 \times 150 \mathrm{~mm} \mathrm{C}_{18}$ HPLC column with gradient elution. Mobile phase A was $0.1 \%(\mathrm{v} / \mathrm{v})$ formic acid in water and mobile phase B was $100 \%$ methanol $(\mathrm{MeOH})$. The column temperature was $30{ }^{\circ} \mathrm{C}$ and the autosampler tray was set to $4{ }^{\circ} \mathrm{C}$. The flow rate was $300 \mu \mathrm{L} / \mathrm{min}$ with 10 minutes equilibration time. The gradient for 3-CNP-R analysis is as follows: $0-4 \min 40 \% \mathrm{~B}$; 4-20 $\min 70 \% \mathrm{~B} ; 20-25 \mathrm{~min}$ $80 \% \mathrm{~B} ; 25-40 \min 40 \% \mathrm{~B}$. The detection of 3-CNP-R was achieved using a Thermo TSQ Quantum Ultra (San Jose, CA) triple-quadrupole mass spectrometer. The HPLC effluent flowed directly into the electrospray interface of the mass spectrometer. The interface was operated in the positive ion mode with a spray voltage of $3.5 \mathrm{kV}$. The ion transfer tube (heated capillary) was set to $325{ }^{\circ} \mathrm{C}$. Precursor ion monitoring focusing on $\mathrm{m} / \mathrm{z} 151.2$ was applied over a scan range of $\mathrm{m} / \mathrm{z} 160-320$ with collision energy of $10 \mathrm{~V}$. Selected ion monitoring (SIM) was used for relative quantitation of radical adducts as compared to external standard curves for 4-(1-pyrrolidino)benzaldehyde and nicotine. Thermo Xcaliber Software was used for chromatographic data analysis. Extracted ion chromatograms were used for identification and relative quantitation of radical species that were reported previously as well as newly proposed radicals. 


\begin{tabular}{lc}
\hline System configuration & Agilent $6890 \mathrm{GC}$ equipped with a $5973 \mathrm{MSD}$ \\
Column & DB-5MS 30 meters, $0.25 \mathrm{~mm} \mathrm{I.} \mathrm{D.,} 0.25 \mu \mathrm{m}$ film thickness \\
Injection port temperature & $280^{\circ} \mathrm{C}$ \\
Injection & Splitless \\
Column flow & Constant, $0.6 \mathrm{~mL} / \mathrm{min} \mathrm{He}$ \\
Column oven initial temperature & $50^{\circ} \mathrm{C}$ \\
Column oven initial time & $0 \mathrm{~min}$ \\
Column oven initial ramp 1 rate & $7.5^{\circ} \mathrm{C} / \mathrm{min}$ \\
Column oven 1 final temperature & $300^{\circ} \mathrm{C}$ \\
Mass spectrometer transfer line temp & $250^{\circ} \mathrm{C}$ \\
Mass spectral databases & $\mathrm{NBS}$, Wiley \\
Mass spectrometer configuration & Electron impact, $70 \mathrm{eV}$ \\
\hline
\end{tabular}

\section{RESULTS AND DISCUSSION}

Solution trapping of mainstream cigarette smoke carboncentered free radicals with impingers containing 3-CNP dissolved in acetone or acetonitrile proved to be suitable for qualitative determination. However, relative quantitation experiments demonstrated that the reactions between 3-CNP were not instantaneous and free radicals were thus not suited to solution trapping. LC-MS/MS and GC/MS experiments yielded similar results with methylaminocarbonyl (acetamide) and acetyl (acyl) radicals being the most abundant radicals observed. The selectivity and sensitivity of LC-MS/MS precursor ion monitor- ing provided data with more radical candidates as whole smoke (WS) background was minimized compared to the background observed with GC-MS. The proficiency for GC-MS to detect a relatively limited number of 3-CNP-R adducts in mainstream vapor phase smoke (MSVP) was established. From GC-MS total ion current chromatograms (TICs) for the 4 MSVP smoke traps containing $5 \mathrm{~mL}$ of a $100 \mu \mathrm{g} / \mathrm{mL}$ solution of 3-CNP in acetone, several observations were made. First, excess 3-CNP does not appear until the third trap, indicating total 3-CNP consumption in traps 1 and 2, and the profile of components in the four traps are unique one to another. Also not shown, a similar trend was observed for the WS experiments.

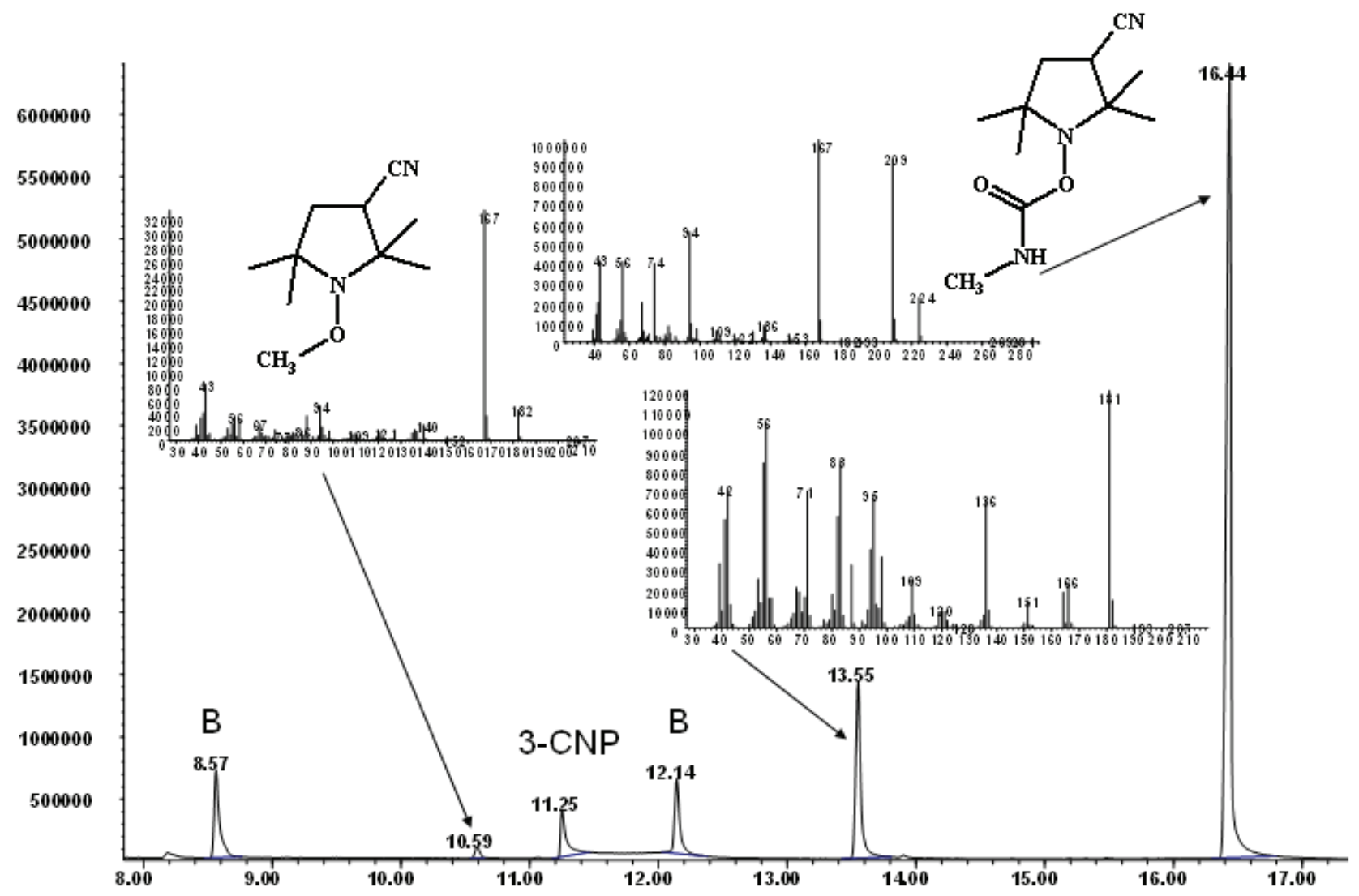

Figure 1. GC/MS total ion chromatogram of 2R4F MSVP smoke exposed to trap four containing $5 \mathrm{~mL}$ of $100 \mu \mathrm{g} / \mathrm{mL} 3 \mathrm{CNP}$ 

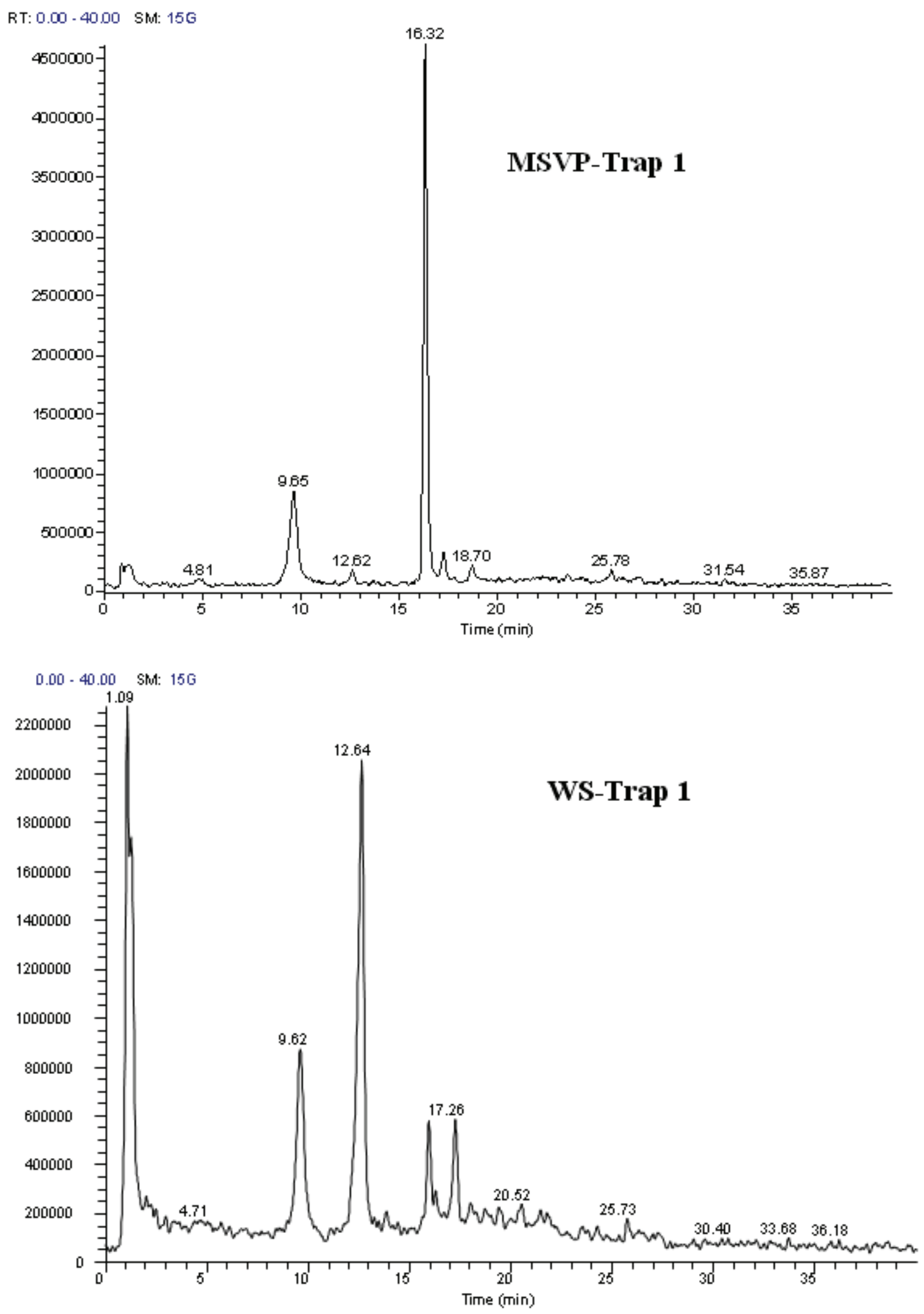

Figure 2. LC-MS/MS precursor ion monitoring of $\mathrm{m} / \mathrm{z} 151.2$ total ion chromatograms (m/z 160-320) of 2R4F MSVP and WS exposed to Trap 1 containing $5 \mathrm{~mL}$ of $500 \mu \mathrm{g} / \mathrm{mL} 3-\mathrm{CNP}$. 
Further examination of the mass spectra of the components appearing in trap 4 shown in Figure 1 revealed several important observations. First, components (B) at retention times, 8.57 and $12.14 \mathrm{~min}$ were present in the $3-\mathrm{CNP}$ solution prior to exposure to MSVP smoke. Also, the mass spectrum of the component at $10.59 \mathrm{~min}$ is consistent with a 3-CNP product with a methyl free radical, $\mathrm{m} / \mathrm{z} 182$, and the mass spectrum of the component at $16.44 \mathrm{~min}$ is consistent with a 3-CNP product with methylaminocarbonyl free radical, m/z 224. Lastly, a clear structural assignment of the component at $13.55 \mathrm{~min}$ is not apparent at this time. Close examination of the TICs for trap 3 (not shown) revealed a relatively minor component at 13.90 minutes. The mass spectrum of this component is consistent with a 3-CNP product with an acetyl radical, $\mathrm{m} / \mathrm{z}=210$. Thus, to this point a GC/MS analytical approach to acetone trapped MSVP smoke has led to the readily straight forward identification of three radical species, methyl, methylaminocarbonyl and acetyl. However, the absence of sufficient 3-CNP reagent in the traps prompted additional experiments wherein the concentration of 3-CNP was increased to $500 \mu \mathrm{g} / \mathrm{mL}$.

When using the higher 3-CNP concentration, an additional MSVP component at retention time 16.38 minutes was discovered in traps 2, 3 and 4, having the mass spectrum consistent with the acrolein analog radical/3-CNP-R adduct with $\mathrm{m} / \mathrm{z}=222$. Examination of the four separate traps exposed to $2 \mathrm{R} 4 \mathrm{~F}$ WS revealed the presence of methyl, ethyl or formyl (m/z 196 for both), methyl- aminocarbonyl, and acetyl radicals. These radical 3-CNP WS reaction products were identical to those found in the MSVP smoke investigations.

The LC-MS/MS TICs for MSVP and WS from the trap 1 containing $5 \mathrm{~mL}$ of a $500 \mu \mathrm{g} / \mathrm{mL}$ solution of $3-\mathrm{CNP}$ in acetone appear in Figure 2. Several observations were made from this Figure including the different array of peaks, most notably, the peak at $16.32 \mathrm{~min}$ that is predominate in MSVP which corresponds to $\mathrm{m} / \mathrm{z} 247$ and 269 (unassigned radicals), and the peak at $12.64 \mathrm{~min}$ in WS which correspond to $\mathrm{m} / \mathrm{z} 226$, or the methylaminocarbonyl radical. The peak at 9.65 min seen in both MSVP and WS corresponds to the 3-CNP reagent peak, indicating an excess of radical scavenging reagent.

Free radicals are most often known for their reactivity and short lifetimes. However, free radicals can be readily detected via electron spin resonance spectrometry in aged cigarette smoke samples (11). Thus, some degree of relative stability does exist. In an attempt to gain some insight on this phenomenon, WS and MSVP smoke samples were captured in four traps containing acetonitrile and no 3-CNP. At selected times after completion of smoke collection and at room temperature, concentrated $\mu \mathrm{L}$ amounts of 3-CNP in acetonitrile were added to a known volume of acetonitrile from each of the traps. The area counts of the acetyl, $\mathrm{C}(\mathrm{O})-\mathrm{CH}_{3}$, radical 3-CNP reaction product, monitored as a function of time, are shown in Figure 3.

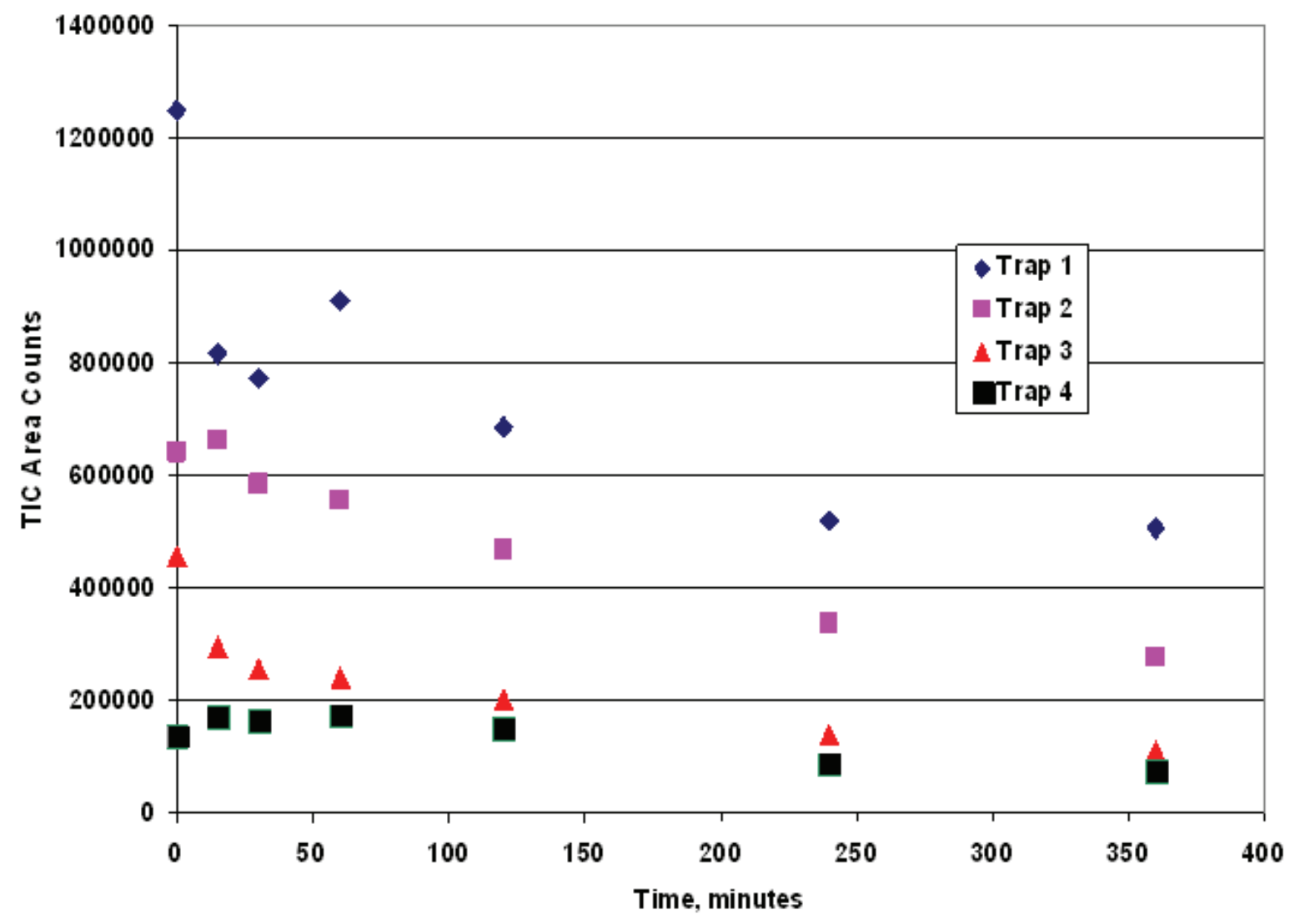

Figure 3. Profile of whole smoke acyl free radical content as a function of time 
The figure does confirm that the concentration of the acyl free radical does decrease with time, however, after six hours, a notable amount of radical still existed. These results do speak to a certain radical or radical adduct instability and reactivity in solution that would have to be addressed should relative free radical quantitative analyses be needed.

Using LC-MS/MS extracted ion chromatograms, 14 carbon-centered free radicals were detected in WS and 10 in MSVP with several at relatively low intensity.

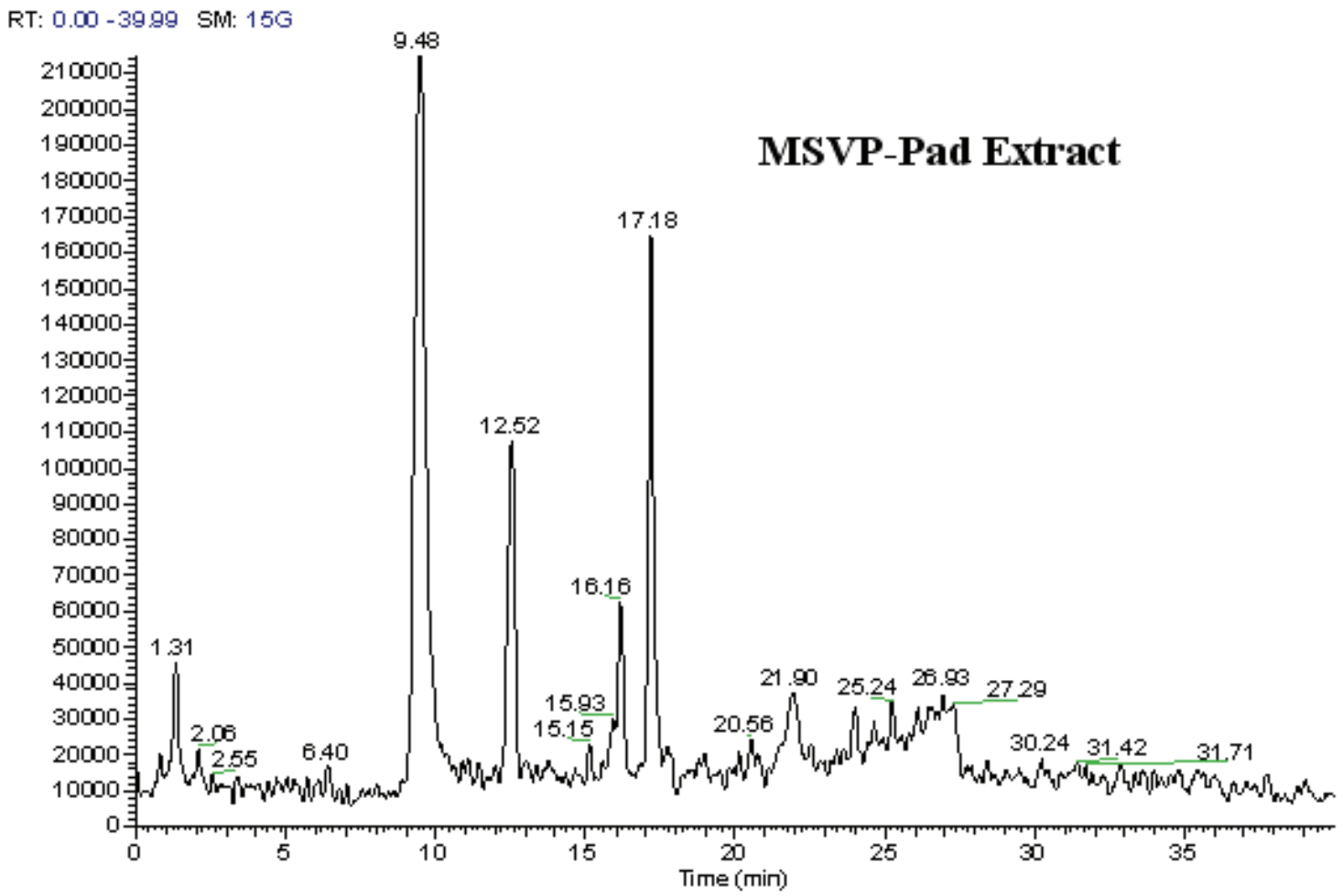

RT: $0.00-39.99$ SM: $15 G$

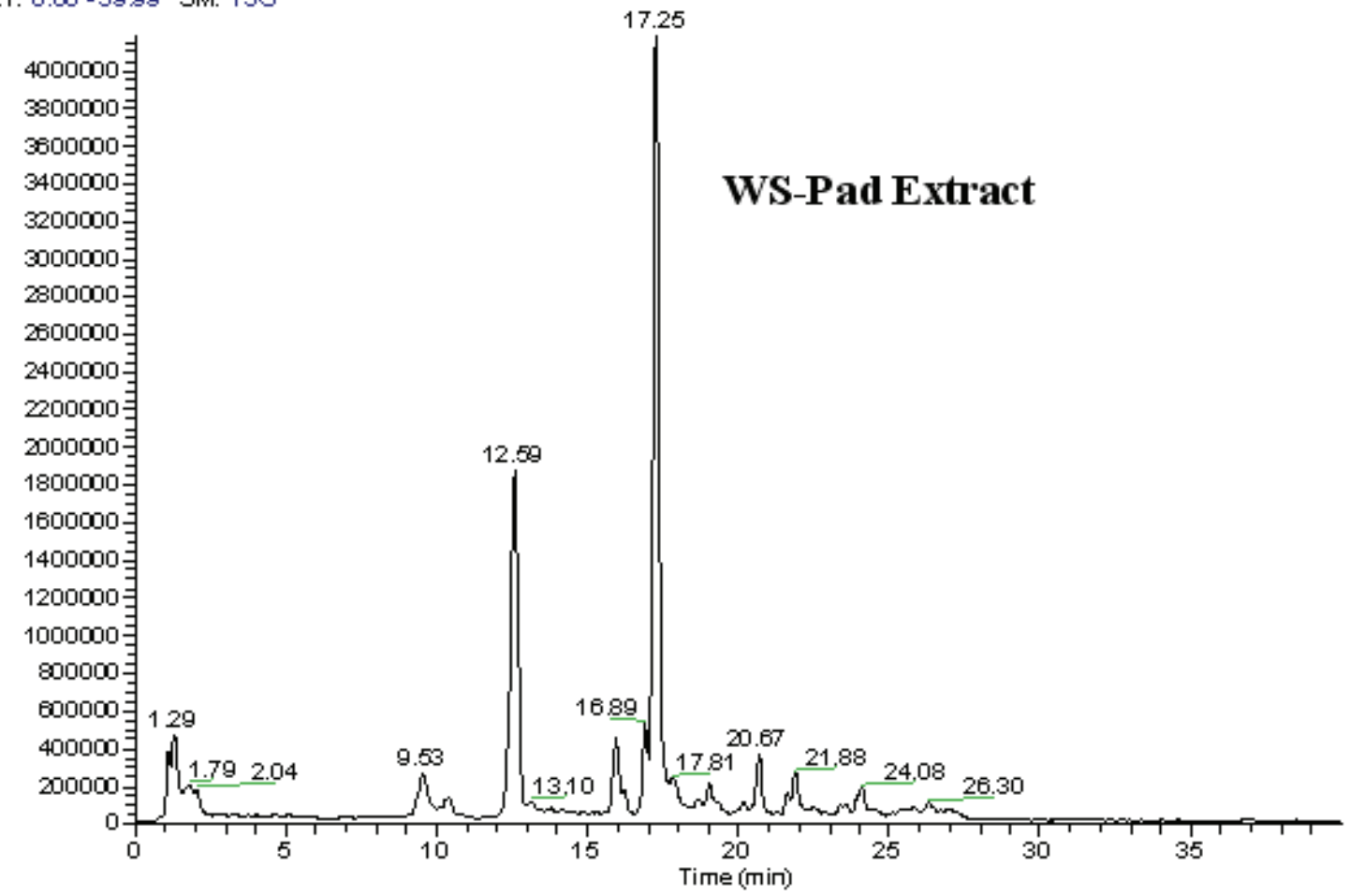

Figure 4. LC-MS/MS precursor ion monitoring of $\mathrm{m} / \mathrm{z} 151.2$ total ion chromatograms $(\mathrm{m} / \mathrm{z} 160-320)$ of $2 R 4 \mathrm{~F}$ mainstream vapor phase (MSVP) and whole smoke (WS) exposed to Cambridge Filter Pad coated with $50 \mathrm{mg}$ of 3-CNP and extracted in 50 mL of 95:5 (v:v) ACN: $\mathrm{H}_{2} \mathrm{O}$. 
The two classes of carbon-centered radicals previously reported in cigarette smoke1 $(9,20)$, acyl $(\mathrm{C}(\mathrm{O})-\mathrm{R})$ and alkyl-aminocarbonyl ( $\mathrm{C}(\mathrm{O})-\mathrm{NH}-\mathrm{R})$, are represented here. However, the proposition of $\mathrm{R}$ groups containing unsaturated substitutions, such as crotonyl radical, is novel. This further supports earlier observations $(19,25)$ that precursors to carbonyl compounds, such as cellulose and other polysaccharides, are responsible for much of the radical formation that occurs in smoke.

The LC-MS/MS TICs from the 3-CNP coated Cambridge filter pads experiments for WS and MSVP are shown in
Figure 4. Several key observations noted were the array of peaks in MSVP and WS are different and MSVP relative abundance of 3-CNP derivatized radicals is over 1 order of magnitude less than WS, indicating the radicals most likely react with vapor phase smoke components or could be stabilized in the particulate phase. The total mass spectra of the entire chromatogram for mass range $\mathrm{m} / \mathrm{z}$ 160-320 for both 2R4F MSVP and WS obtained from LC-MS/MS precursor ion analysis of 3-CNP coated Cambridge filter pads are shown in Figure 5.
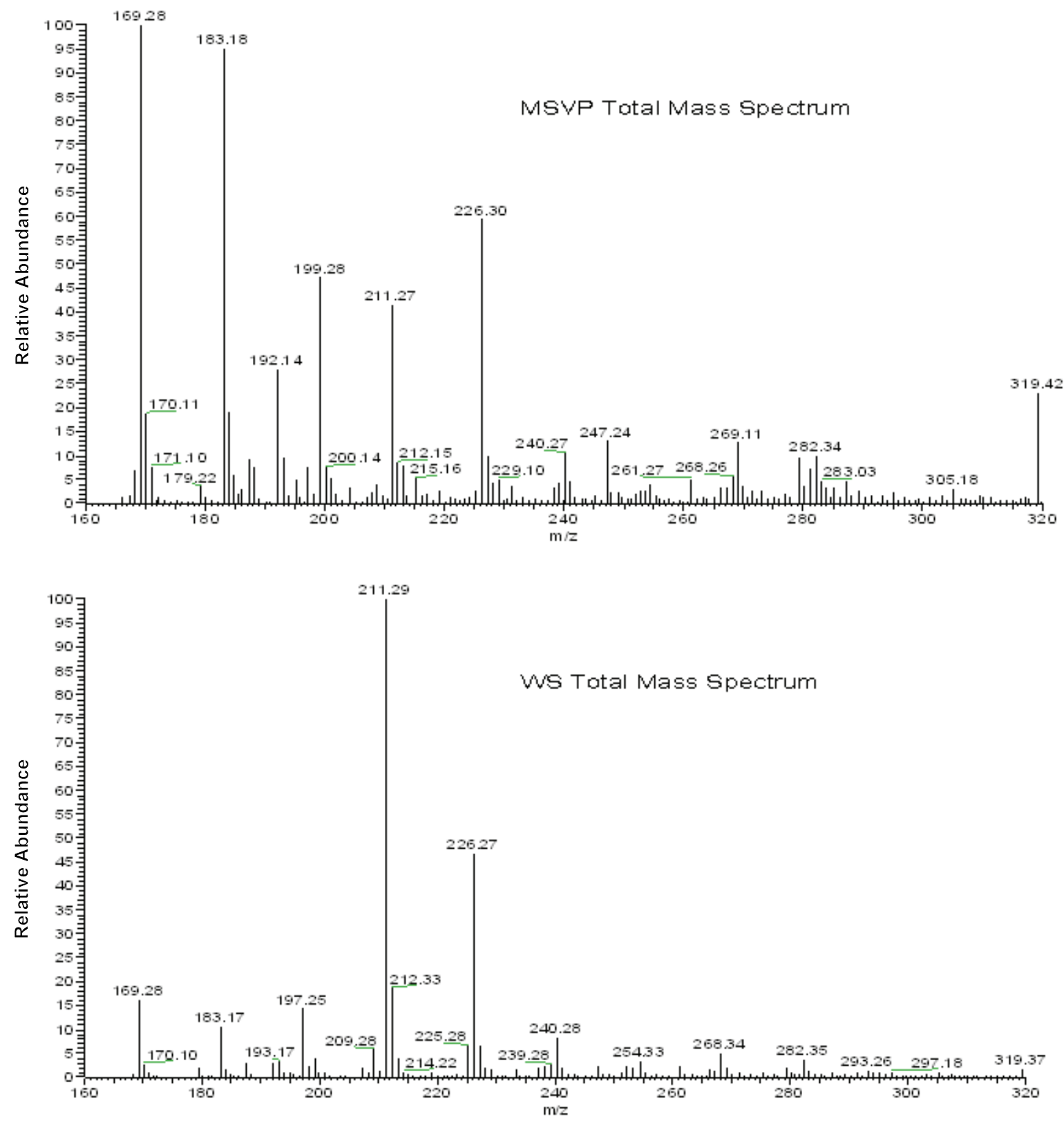

Figure 5. LC-MS/MS precursor ion monitoring of $\mathrm{m} / \mathrm{z} 151.2$ total mass spectrum $(\mathrm{m} / \mathrm{z} 160-320)$ of $2 \mathrm{R} 4 \mathrm{~F}$ mainstream vapor phase (MSVP) and whole smoke (WS) exposed to Cambridge Filter Pad coated with $50 \mathrm{mg}$ of 3-CNP and extracted in $50 \mathrm{~mL}$ of 95:5 (v:v) $\mathrm{ACN}: \mathrm{H}_{2} \mathrm{O}$ 


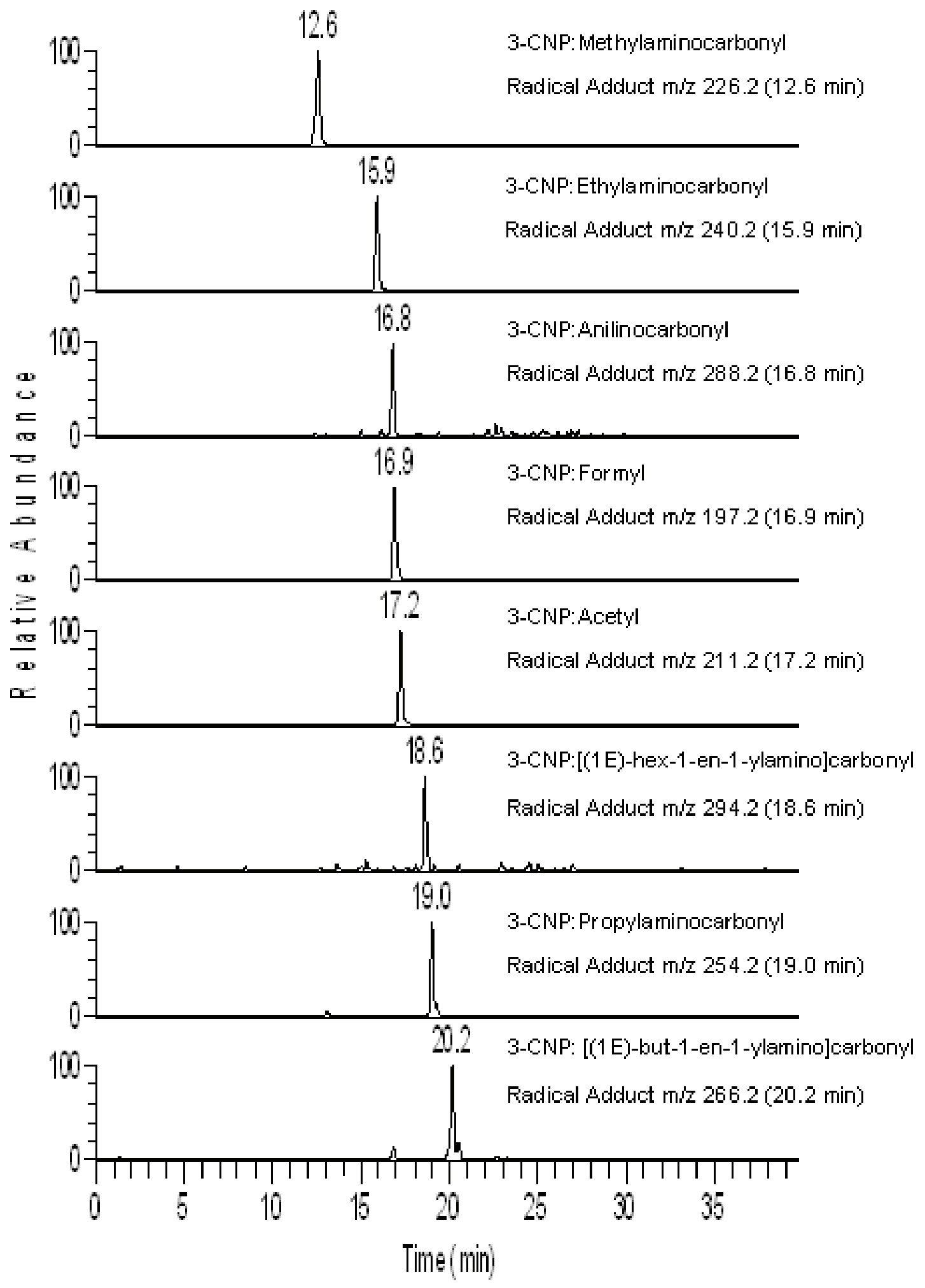

Figure 6. LC-MS/MS extracted ion chromatograms of 2R4F WS exposed to Cambridge Filter Pad coated with 50 mg of 3-CNP and extracted in $50 \mathrm{~mL}$ of $95: 5$ (v:v) $\mathrm{ACN}: \mathrm{H}_{2} \mathrm{O}$ 


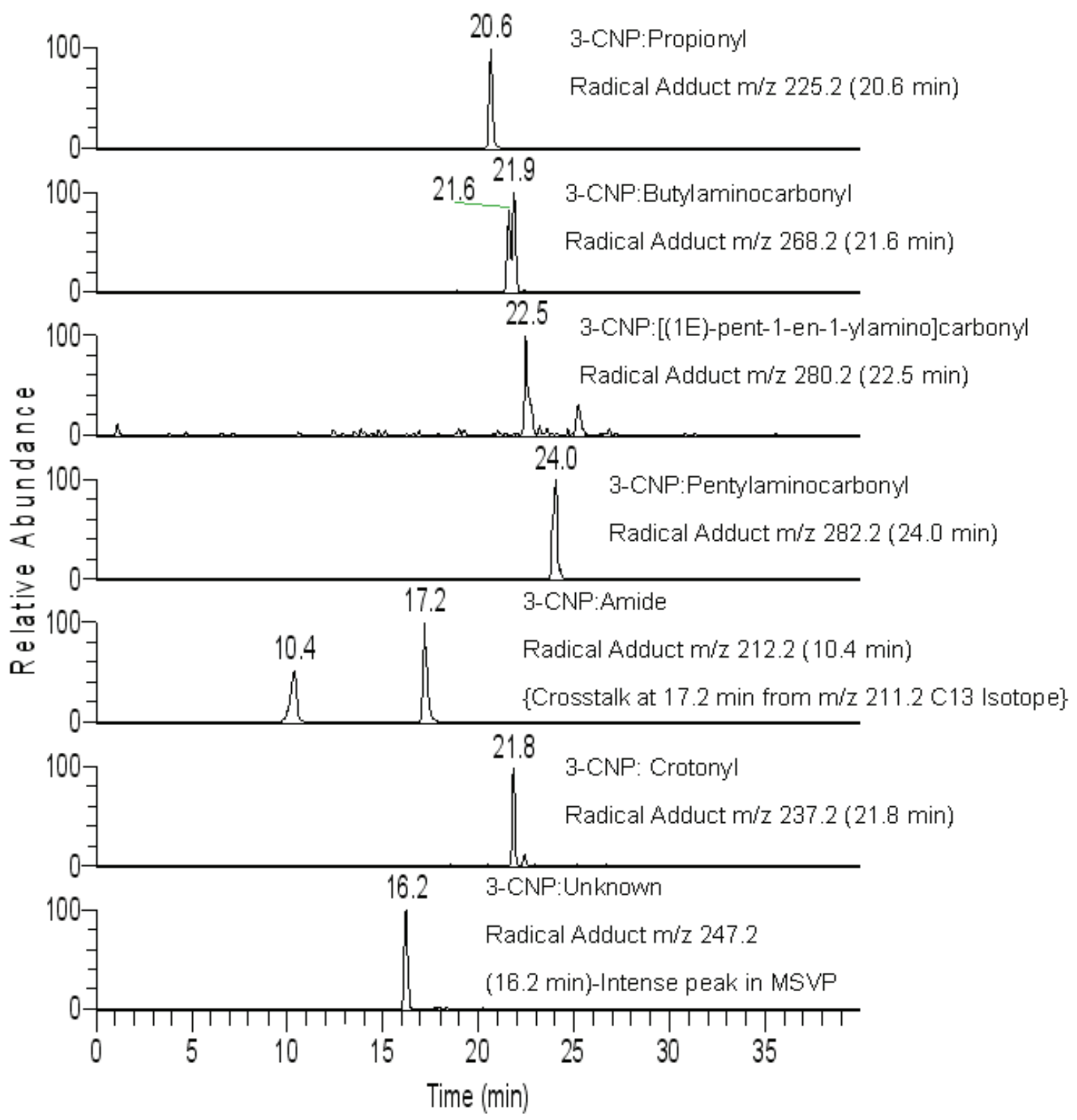

Figure 6. LC-MS/MS extracted ion chromatograms of 2R4F WS exposed to Cambridge Filter Pad coated with $50 \mathrm{mg}$ of 3-CNP and extracted in $50 \mathrm{~mL}$ of 95:5 (v:v) ACN: $\mathrm{H}_{2} \mathrm{O}$

The vast difference in the array of spectra in MSVP and WS was observed, however, ions of $\mathrm{m} / \mathrm{z} 211$ and 226, corresponding to acetyl and methylaminocarbonyl radicals, respectively, are 2 of the most abundant ions in both MSVP and WS.

LC-MS/MS extracted ion chromatograms of 2R4F WS exposed to Cambridge Filter Pads are shown in Figure 6. Chromatograms representative of 15 different ions are revealed, 14 of which have been assigned structural identifications. The following carbon-centered radicals have not been reported and are therefore proposed, though no other structural identification was performed: formyl $(\mathrm{CHO})$ or ethyl $\left(\mathrm{C}_{2} \mathrm{H}_{5}\right)$ radical, amide $\left(\mathrm{CH}_{2} \mathrm{NO}\right)$, crotonyl $\left(\mathrm{C}_{4} \mathrm{H}_{5} \mathrm{O}\right),\left[(2 \mathrm{E})\right.$-pent-2-en-1-ylaminocarbonyl $\left(\mathrm{C}_{6} \mathrm{H}_{10} \mathrm{NO}\right)$, anilinocarbonyl $\left(\mathrm{C}_{7} \mathrm{H}_{6} \mathrm{NO}\right)$. The other seven carbon centered radicals have been proposed in previous work $(19,20)$. The structures for the proposed carbon-centered radicals appear in Table 2, and the previously reported radicals appear in Table 3. 
Table 2. Proposed structures of carbon-centered free radicals in whole smoke (WS). ("Detected by GC/MS only)

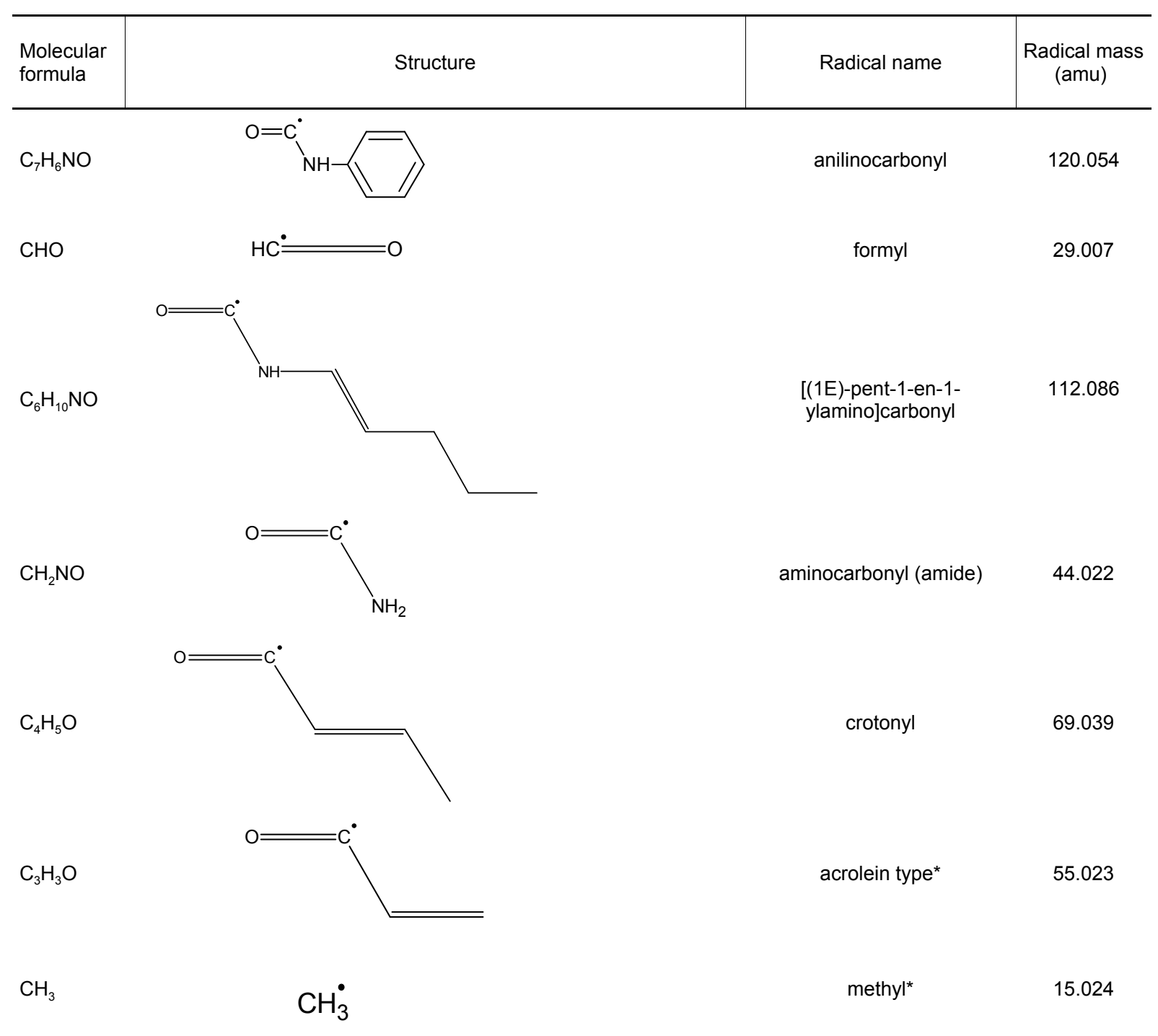

The relative abundance (area counts) of 14 radicals reported here by LC-MS/MS precursor ion monitoring appear in Table 4. Several observations can be made from this table. First, it is apparent that the methylaminocarbonyl (acetamide) radical and acetyl (acyl) radical are the most abundant radicals and account for a vast majority of the sum of all radicals. Second, the carbon-centered radicals' relative abundance is greatly skewed towards WS. Perhaps the radicals react in the whole smoke matrix of the first, uncoated pad before reaching the second, coated pad or the radicals are short-lived in the vapor phase. Since radicals were present after 6 hours as mentioned previously in radical fate experiments, it is assumed the radicals are stabilized in the particulate phase as reported $(11,15)$.

The relative abundance of carbon centered free-radicals was calculated using external standard calibrations of 4-(1pyrrolidino)benzaldehyde and nicotine. The calibration curve equations for 4-(1-pyrrolidino)benzaldehyde and nicotine were $\mathrm{y}=5.96 \mathrm{x}-24.3\left(\mathrm{R}^{2}=0.985\right)$ and $\mathrm{y}=1.87 \mathrm{x}$ $-18.5\left(\mathrm{R}^{2}=0.983\right)$, respectively, with LC-MS/MS SIM. The sum of the 3 most abundant radical adducts was determined to be approximately $265 \mathrm{nmole} /$ cigarette for reference cigarette $2 \mathrm{R} 4 \mathrm{~F}$ at $35 / 60 / 2$ conditions. This agrees well with published values of 225 nmole carbon-centered radicals per cigarette $(19,20)$. 
Table 3. Structures of carbon-centered free radicals in whole smoke (WS) reported here and in previous work

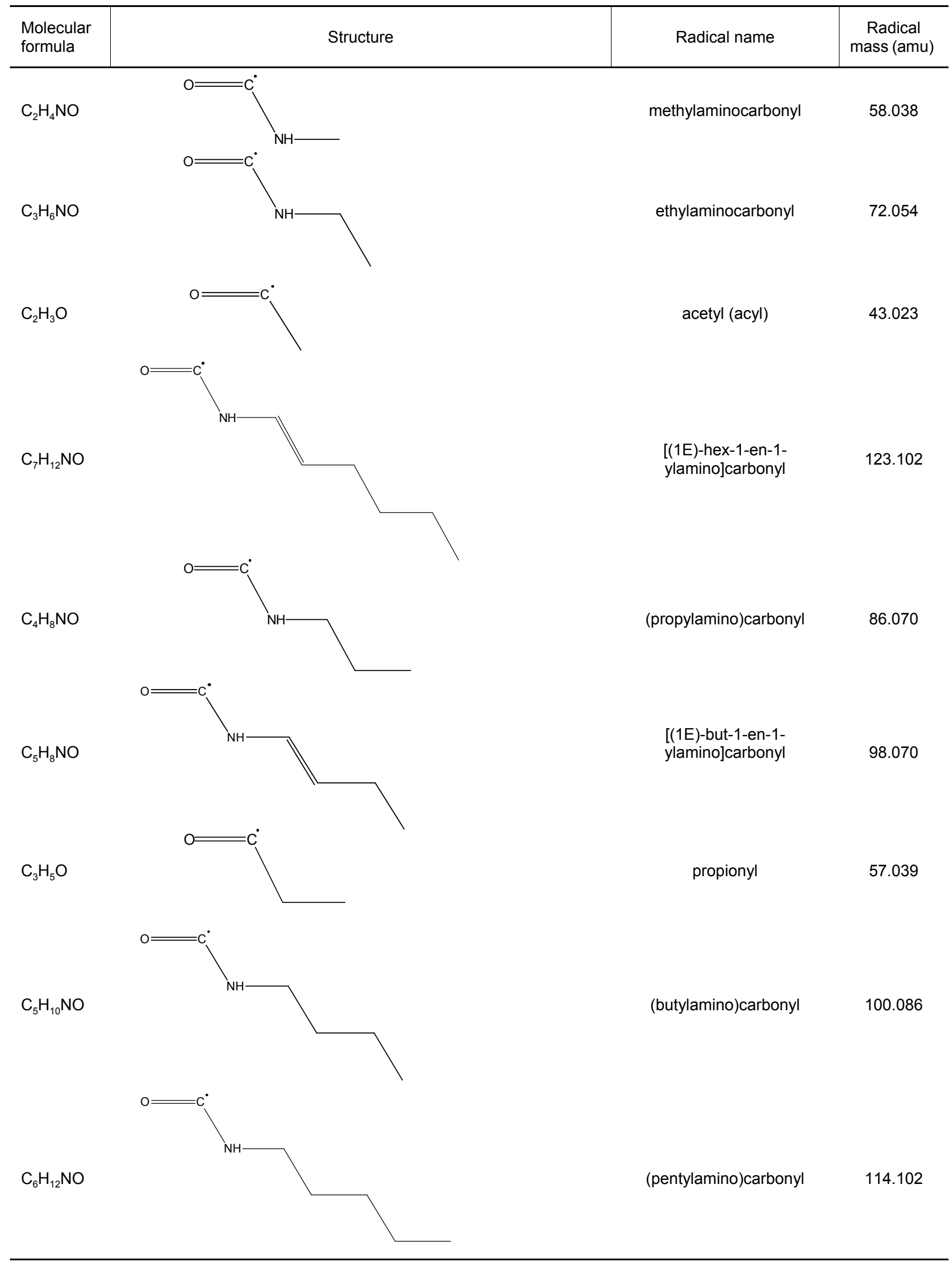


Table 4. LC-MS/MS precursor ion monitoring relative area counts for carbon-centered free radicals in whole smoke (WS) and mainstream vapor phase (MSVP)

\begin{tabular}{lcc|c}
\hline Radical type & MSVP & WS & Ratio (WS/MSVP) \\
\hline (Methylamino)carbonyl & $2,032,382$ & $25,876,095$ & 12.7 \\
(Ethylamino)carbonyl & 232,055 & $4,341,270$ & 18.7 \\
Anilinocarbonyl & 5,895 & 53,987 & 9.2 \\
Formyl & 19,177 & $5,907,293$ & 308.0 \\
Acetyl & $1,672,986$ & $50,988,651$ & 30.5 \\
[(1E)-hex-1-en-1-ylamino]carbonyl & 2,232 & 87,522 & 39.2 \\
(Propylamino)carbonyl & 59,102 & $1,387,597$ & 23.5 \\
[(1E)-but-1-en-1-ylamino]carbonyl & 40,399 & 539,550 & 13.4 \\
Propionyl & 34,654 & $2,949,115$ & 85.1 \\
(Butylamino)carbonyl & 74,295 & 927,607 & 12.5 \\
[(1E)-pent-1-en-1-ylamino]carbonyl & 14,603 & 158,575 & 10.9 \\
(Pentylamino)carbonyl & 109,209 & $1,721,637$ & 15.8 \\
Aminocarbonyl & 2,801 & $3,305,211$ & 1180.1 \\
Crotonyl & 1,385 & 632,276 & 456.6 \\
Total area & $4,301,174$ & $98,876,384$ & 23.0 \\
\hline
\end{tabular}

\section{CONCLUSIONS}

From a relatively simple collection procedure, radical trapping in solution, followed by analyses employing GC/MS, valuable qualitative information on the nature of carboncentered free radicals in cigarette smoke can be obtained. An even simpler approach using a coated Cambridge filter pad can be used to effectively trap free radicals from cigarette smoke. With a highly sensitive and selective LC$\mathrm{MS} / \mathrm{MS}$, it is possible to identify and semi-quantitate 14 carbon-centered radicals in WS and MSVP. Based on these results, correlation between carbon-centered free radical types and concentrations can be developed as a function of cigarette prototype configurations and possibly smoking parameters. In addition, correlation between carbon-centered free radical types and concentrations can be developed as a function of in vitro biological assays.

\section{REFERENCES}

1. Hecht, S.S.: Tobacco carcinogens, their biomarkers and tobacco-induced cancer; Nat. Rev. Cancer. 3 (2003) 733-744.

2. Hecht, S.S.: Tobacco smoke carcinogens and lung cancer; J. Natl. Cancer Inst. 91 (1999) 1194-1210.

3. Pryor, W.A.: Cigarette smoke radicals and the role of free radicals in chemical carcinogenicity; Environ. Health Perspect. 105 (1997) 875-882.

4. Pryor, W.A., B.J. Hales, P.I. Premovic, and D.F. Church: The radicals in cigarette tar: their nature and suggested physiological implications; Science. 220 (1983) 425-427.

5. Pryor, W.A., K. Stone, L-Y Zang, and E. Bermudez: Fractionation of aqueous cigarette tar extracts: fractions that contain the tar radical cause DNA damage; Chem. Res. Toxicol. 11 (1998) 441-448.

6. Alexandrov. K., M. Rojas, and C. Rolando: DNA damage by benzo $[a]$ pyrene in human cells is increased by cigarette smoke and decreased by a filter containing rosemary extract, which lowers free radicals; Cancer Res. 66 (2006) 11938-11945.

7. Wooten, J.B., S. Chouchane, and T.E. McGrath: Tobacco Smoke Constituents Affecting Oxidative Stress; in: Cigarette Smoke and Oxidative Stress, edited by B.B. Halliwell and H.E. Paulsen, Chap. 2, Berlin, Springer, 2006, pp. 5-15.

8. Pryor, W.A., K. Terauchi, and W.H. Davis: Electron spin resonance (ESR) study of cigarette smoke by use of spin trapping techniques; Environ. Health Perspect. 16 (1976) 161-175.

9. Pryor, W.A., K. Terauchi, and D.F. Church: ESR spintrapping study of the radicals produced in nitrogen oxide (NOx)/olefin reactions: a mechanism for the production of the apparently long-lived radicals in gasphase cigarette smoke; J. Am. Chem. Soc. 106 (1984) 5073-5079.

10. Pryor, W.A., D.G. Prier, and D.F. Church: Electronspin resonance study of mainstream and sidestream cigarette smoke: nature of the free radicals in gasphase smoke and in cigarette tar; Environ. Health Perspect. 47 (1983) 345-355.

11. Church, D.F., and W.A. Pryor: Free-radical chemistry of cigarette smoke and its toxicological implications; Environ. Health Perspect. 64 (1985) 11-126.

12. Pryor, W.A.: Cigarette smoke and the involvement of free radical reactions in chemical carcinogenesis; J. Cancer Suppl. 8 (1987) 19-23.

13. Baker, R.R.: Production Chemistry, Chemistry and Technology; in: Tobacoo, edited by E.L. Davis, M.T. Nielson, Oxford, Blackwell Science, 1999, pp. 398-439.

14. Baum, S.L., I.G.M. Anderson, R.R. Baker, D.M. Murphy, and C.C. Rowlands: Electron spin resonance and spin trap investigation of free radicals in cigarette smoke: development of a quantification procedure; Anal. Chim. Acta. 481 (2002) 1-13. 
15. Blakley, R.L. D.D. Henry, and C.J. Smith: Lack of correlation between cigarette mainstream smoke particulate phase radicals and hydroquinone yield; Food Chem. Toxicol. 39 (2001) 401-406.

16. Borgerding, M.F., R.L. Blakley, L.S. Winkler, D.D. Henry, G.L. Bowman, and D.H. Smith: Methodology for the determination of free radicals in mainstream vapor phase cigarette smoke, in: Proceedings of the Paper Presented at the $47^{\text {th }}$ Tobacco Chemists Research conference, Lexington, KY, USA, 1995, Programme Booklet and Abstracts (abstract no. 58).

17. Flicker, T.M. and S.A. Green: Detection and separation of gas-phase carbon-centered radicals from cgarette smoke and Diesel Exhaust; Anal. Chem. 70 (1998) 2008-2012.

18. Flicker, T.M. and S.A. Green: Comparison of gasphase free-radical populations in tobacco smoke and model systems by HPLC; Environ. Health Perspect. 109 (2001) 765-771.

19. Bartalis, J., W.G. Chan, and J.B. Wooten: A new look at radicals in cigarette smoke; Anal. Chem. 79 (2007) 5103-5106.

20. Bartalis, J., Y.L. Zhao, J.W. Flora, J.B. Paine, and J.B. Wooten: Carbon-centered radicals in cigarette smoke: acyl and alkylaminocarbonyl radicals; Anal. Chem. 81 (2009) 631-641.

21. Emami, I., D. Masselot, S. Le Gac, and C. Rolando: A new and efficient method for detecting free radicals by LC-MS/MS. Application to the optimization of a cigarette filter which remove free radicals in cigarette smoke; CORESTA Congress, 2002, New Orleans, USA Abstr. SSPT 39, p. 18, (accessed August 2010) http://www.coresta.org/Past_Abstracts/NewOrleans 2002-SmokeTech.pdf
22. Rolando, C., F. Cantais, and I. Emami: Precise identification of free radicals in cigarette smoke by exact mass measurement using nano-LC, nano-ESI FT-MS/MS; CORESTA Congress, 2006, Paris, France Abstr. SSPT 54, p. 25, (accessed August 2010) http://www.coresta.org/Past_Abstracts/Paris2006SmokeTech-Oct06.pdf

23. Le Faouder, P., C. Tokarski, I. Emami, and C. Rolando: Identification and quantitation of free radical content in cigarette smoke using nano-LC nano-ESI FT-MS/MS; CORESTA Congress, 2008, Shanghai, China Abstr. SSPT 32, p. 17 (accessed August 2010) http://www.coresta.org/Past_ Abstracts/Shanghai2008-SmokeTech.pdf

24. Moldoveanu S.C., W.M. Coleman III, and J.M. Wilkins: Determination of Carbonyl Compounds in Exhaled Cigarette Smoke; Beitr. Tabakforsch. Int. 22 (2007) 346-352.

25. Pryor, W.A., M. Tamura, M.M. Dooley, P. Premovic, B.J. Hales, and D.F. Church: In: Oxy Radicals and their Scavenger Systems. Volume II: Cellular and Medical Aspects; edited by R.A. Greenwald and G. Cohen, New York, NY, Elsevier, 1983.

Address for correspondence:

Anthony R. Gerardi

R.J. Reynolds Tobacco Co.

950 Reynolds Boulevard

Winston-Salem, NC 27105, USA

E-Mail: gerarda@rjrt.com 